\title{
LITERASI DIGITAL DAN ETIKA MEDIA SOSIAL DI ERA POST-TRUTH
}

\author{
Puji Rianto \\ puji.rianto@uii.ac.id \\ Program Studi Ilmu Komunikasi, Fakultas Psikologi dan Sosial Budaya, \\ Universitas Islam Indonesia
}

\begin{tabular}{l} 
Article Info \\
\hline Keyword: \\
WhatsApp, post-truth, digital \\
literacy, and ethics
\end{tabular}

\section{PENDAHULUAN}

John Berger (1972; Grossberg et. al, 2006: 199) mengemukakan bahwa media adalah suatu cara melihat (the way of seeing) realitas, menyangkut bagaimana subjek direpresentasikan dan melalui praktik-praktik representasi memunculkan suatu sistem berfikir mengenai nilai-nilai individu. Media sering menasbihkan orang-orang sukses atau mendefinisikan mana yang dianggap bernilai dan tidak. Kesemuanya mempengaruhi individu dalam memandang realitas di sekelilingnya, termasuk dalam memandang dirinya sendiri. Oleh karena itu, setiap individu harus mempunyai 'kesadaran' kritis dalam mengenali realitas media, dan mampu membedakannya dengan realitas sosial. Untuk itu, setiap individu harus mampu "mengontrol" media. Ini telah menjadi salah satu tujuan penting literasi media. Sebagaimana dikemukakan Potter (2011: 8), "Taking control is what media literacy is all about." Dalam pandangan Potter, jika kita mempunyai literasi media yang baik maka akan memberikan perspektif yang lebih jelas untuk melihat batas-batas antara dunia nyata dan media. Jika kita mampu membedakan antara realitas sosial dan realitas media, maka kita akan lebih mampu menggunakan media secara lebih kritis dan tidak mudah 'dimanipulasi'. Inilah yang menjadi latar belakang banyak gerakan literasi media literasi di Indonesia (lihat Poerwaningtias dkk, 2009; Kurnia dan Santi, 2017; Sarwono, Hendriyani, dan Guntarto, 2011; Mutmainnah, 2011; Guntarto, 2011; Poerwaningtias dkk, 2009)). Kebutuhan literasi media itu semakin kuat oleh tuntutan media digital yang jauh lebih "radikal"dalam memfasilitasi komunikasi manusia. Media digital bukan hanya menghilangkan "gatekeeper" dalam media konvensional (old media), tapi sekaligus mengaburkan batas-batas antara pemrodusen dan penerima pesan. Media baru menawarkan dunia yang mirip dengan dunia nyata. Media baru menyediakan ruang chatting, conference, ataupun percakapan dalam dunia politik sehingga pesan, informasi ataupun propaganda politik dapat secara viral (Madrah dan Mubarak, 2018: 19). Post-truth berkembang luas di era 
media digital ini (Kapolkas, 2019). Kemampuan media baru dalam memfasilitasi pengguna untuk memproduksi, berbagi, dan menyebarkan komunikasi memungkinkannya untuk digunakan kelompok politik untuk membangun narasi demi tujuan-tujuan politiknya.

Di Indonesia, fenomena post-truth dapat dibaca dengan jelas selama pemilu 2019, dan banyak orang menggunjingkan hal itu. Polarisasi politik terjadi dan berlangsung masif. Identitas kelompok mudah dibaca terutama dari pilihan-pilihan media dan pesanpesan media yang dikonsumsi dan dibagi di media sosial seperti Facebook, Twitter, Instagram, dsb. Media baru memfasilitasi pembelahan itu melalui sifat "otonomi" pengguna dalam mengonsumsi, memroduksi, dan menyebarkan pesan media. Akibatnya, para pengguna (user)-untuk membedakannya dengan khalayak tradisional (lihat Lester dkk, 2006)-mudah terjebak ke dalam post-truth.

Studi ini dilakukan untuk menjawab pertanyaan bagaimana fenomena post-truthberlangsung dalam kelompok percakapan WhatsApp? Sejauh mana literasi digital mampu menjadi sarana penggunaan media yang kritis dan reflektif di era di mana orang-orang hanya ingin mendengar dan melihat apa yang mereka ingin lihat dan dengar (Kapolkas, 2012; Moravec et.al, 2018; Block, 2019)?; dan di mana peran etika dalam situasi semacam itu?

Penelitian ini melanjutkan penelitian saya sebelumnya (Rianto, 2016). Penelitian dengan menggunakan studi partisipasi observasi itu menyimpulkan bahwa orang-orang cenderung memilih dan membagikan informasi yang disesuaikan dengan keyakinan mereka. Ini membuat mereka mudah terjebak ke dalam kebenaran tunggal karena peluang mendapatkan informasi 'versi lain' tertutup (lihat Kelkar, 2019). Situasi ini semakin diperparah oleh segregasi politik yang difasilitasi media sosial. Kelompok ini cenderung eksklusif dan mengakses informasi dalam batas-batas yang disesuaikan oleh minat dan keinginan-keinginan mereka (Jatmiko, 2019).

Asumsi dasar penelitian ini adalah fenomena post-truth tidak dapat disandarkan semata pada literasi digital yang selama ini menjadi fokus banyak sarjana komunikasi di Indonesia. Sebaliknya, etika media sosial harus menjadi sandaran lainnya. Ini tidak berarti bahwa literasi digital tidak diperlukan atau tidak penting, tapi semata literasi digital tidaklah cukup ketika berhadapan dengan orang-orang yang hanya percaya pada apa yang ingin mereka percayai. Studi ini diharapkan memperkaya kajian post-truth di Indonesia yang mulai banyak dilakukan seperti studi Jatmiko (2019) mengenai post-truth dan pembelahan politik pilpres, Utami (2018) mengenai hoax pilkada Jakarta 2017, dan Rianto, et.al, (2019) mengenai hoax politik pilpres 2019. Dengan memfokuskan pada etika, studi ini akan melengkapi kajian-kajian etika media massa lebih dulu menarik minat ilmuwan sosial dan komunikasi (lihat, misalnya, Hanugraheningtias, 2015; Tabroni, 2012) ataupun etika media baru (Prajarto, 2011)

\section{KAJIAN PUSTAKA}

\section{Metodologi}

Penelitian ini menggunakan etnografi atau lebih tepatnya online etnografi atau netnografi menurut Kozinets (2015). Sama dengan etnografi konvensional di mana fokus penelitiannya adalah budaya dan komunitas, online etnography fokus pada komunitas daring. Data diambil melalui observasi partisipasi terhadap kelompok percakapan WhatApps dari suatu kumpulan alumni salah satu universitas di Yogyakarta. Kelompok percakapan tersebut dipilih karena setidaknya tiga alasan. Pertama, keragaman anggotanya. Anggota kelompok ini berasal dari latar belakang budaya yang berbeda, baik dari sisi suku, agama, dan sosialekonomi. Satu-satunya yang menyatukan merekaadalah pengalaman masa lalu sebagai mahasiswa yang pernah hidup dalam satu asrama. Meskipun awalnya sebagian besar berasal dari kelompok kelas menengah bawah, tapi kemudian berhasil melakukan transformasi kelas dengan beragam pekerjaan atau profesi. Ada yang menjadi politikus, pejabat publik, lawyer, dokter, pengusaha, jurnalis, militer, guru dan pengajar di perguruan tinggi. Kedua, tidak diragukan lagi, mereka adalah kelompok terdidik karena minimal berpendidikan sarjana atau pascasarjana. Jadi, mereka mampu menggunakan nalar rasional dengan baik. Ketiga, 
keragaman sosiologis dan budaya pada akhirnya membelah mereka, dalam konteks pemilu 2019, ke dalam dua kelompok yang berbeda secara tajam, yakni kelompok yang pro pasangan calon presiden 01 dan 02 .

Data dikumpulkan dari percakapan dalam bentuk teks, gambar, dan grafisyang dipertukarkan dalam grup. Data dianalisis melalui tiga tahap (Miles dan Huberman, 2005). Pada tahap awal, peneliti melakukan pengamatan terlibat, dan menyimak setiap percakapan yang berlangsung dalam kelompok tersebut dengan sesekali memberikan tanggapan atau komentar terhadap unggahan yang dilakukan anggota grup.

Langkah kedua menyalin seluruh percakapan dalam grup tersebut ke dalam teks dalam bentuk dokumen melalui aplikasi yang disediakan WhatsApp. Ada kurang lebih 450 halaman percakapan yang disimpan dalam rentang Maret-April 2019. Namun, setelah dilakukan analisis, peneliti memutuskan untuk memfokuskan pada 16 April 2019 hingga 20 April 2019. Akhirnya, ada 115 halaman percakapan yang kemudian dilakukan analisis. Rentang ini dipilih karena percakapan pada waktu itu sangat tinggi. Pengkategorian dilakukan berdasarkan materi yang diunggah, link atau sumber informasi yang dirujuk, ataupun komentar partisipan dalam menanggapi unggahan yang dianggap hoaks. Selanjutnya, dilakukan pendeskripsian untuk kemudian dilakukan penarikan kesimpulan.

\section{Kajian Konseptual}

Kerangka pemahaman literasi media yang mulai dikaji seiring kemunculan media konvensional mendapatkan tantangan media baru. Sifat media baru yang berbeda dalam banyak hal dengan media lama (old media) seperti media cetak, radio, dan televisi, telah menuntut suatu bentuk 'kecakapan' baru bagi para pengguna (user). Gagasan literasi media baru diharapkan akan membuat para pengguna lebih kritis dalam mengonsumsi, memroduksi, dan menyebarkan pesan-pesan melalui media baru. Ini karena kegagalan atau kekeliruan dalam menggunakan media sosial akan menciptakan kondisi ketidakberdayaan (Vanwynsberghe, Boudry, Verdegem, 2011) sehingga literasi digital menjadi kompetensi yang dibutuhkan untuk menghadapi industri kreatif yang lebih kompetitif dan terwujudnya suatu masyarakat pengetahuan yang inklusif (Gómeza, Tirado-Morueta, dan Hernando-Gómez, 2014); dan kecakapan untuk bertahan hidup (survival skills) (Eshet-Alkalai, 2004; lihat juga Ashley, Maksl, dan Craft, 2017).

Literasi digital juga sangat penting dalam kerangka demokrasi karena mendorong keterlibatan warga negara secara lebih bermakna. Paul Mihailidis berargumen bahwa "media literacy is the path towards more active and robust civic engagement in the 21st century" (Ashley, Maksl, dan Craft, 2017: 79). Jika kualitas demokrasi ditentukan oleh diantaranya informasi yang diterima masyarakat (well-informed) (McNair, 2003), maka kemampuan warga negara dalam menganalisis, mengintepretasi, dan menggunakan media akan memberikannya kapasitas yang lebih baik.

Dibandingkan dengan media konvensional, media baru memberikan banyak kemudahan yang memungkinkan partisipasi lebih luas dari para pengguna dalam komunikasi publik (Swigger, 2012; Nasrullah, 2017). Hilangnya 'gatekeeper' dalam media baru memungkinkan pengguna untuk memroduksi dan menyebarkan pesan komunikasi karena sifatnya yang tidak one to many seperti pada media konvensional, tapi one to one, one to many, many to many, dan seterusnya (lihat Chaffee dan Metzger, 2001). Dalam dunia media baru, bukan hanya profesionalitas menjadi sangat problematis (lihat Nichols, 2019; Kapolkas, 2019), tapi pusat-pusat kekuasaan menyebar dan etika menjadi semakin sulit ditegakkan. Maka, literasi digital diharapkan dapat memberikan kemampuan kepada pengguna untuk berkomunikasi dengan cara yang lebih baik, mengambil manfaat yang lebih banyak bagi para pengguna (Rianto, 2016; Juliswara, 2017; EshetAlkalai, 2004; Potter, 2011; Rahmah, 2015; Galih, 2017; Turow, 2014).

Cervi, Paredes, \& Tornero (2010; dikutip dari Lin et. al, 2013: 161) mengemukakan bahwa literasi digital pada dasarnya merupakan perkembangan lebih lanjut dan komprehensif dari literasi klasik (misalnya membaca dan menulis), literasi audio visual (berhubungan dengan media elektronik), digital literasi (berhubungan dengan teknologi digital), dan yang lebih komprehensif, yakni literasi media baru (berhubungan dengan internet dan web 2.0). Di sini, literasi digital 
dibedakan atas literasi media baru, sedangkan di beberapa literatur lainnya tidak dibedakan antara literasi digital dengan literasi media baru (lihat, misalnya, Kurnia dan Astuti, 2017; Neumann, Finger, Neumann, 2017). Literasi media baru sebagai suatu kerangka literasi media yang lebih komprehensif mencakup semua bentuk literasi, yakni klasik, audio visual, literasi digital, dan literasi informasi (Chen, Wu, dan Wang, 2011).

Secara sederhana, Cen et. all (Lin et. al, 2012) mengemukakan literasi digital atau literasi media baru bersifat multiliterasi, yang mencakup di dalamnya kombinasi antara information literacy skill, conventional literacy skills, and social skills'. Dalam "Unpacking New Media Literacy," Cen et. al (2011: 85) mengemukakan bahwa literasi media baru dapat dipahami dalam dua kontinum, yakni dari consuming literacy ke prosuming literacy dan dari functionality ke critical literacy. Consuming literacy merujuk pada kemampuan mengakses dan menggunakan pesan media dalam beragam tingkatan. Consuming skill ini dapat diperluas ke dalam keterampilan kritis dalam memroses informasi seperti sintesis dan kritik. Prosuming skill di sisi lain merujuk pada kemampuan untuk menghasilkan pesan media sebagai tambahan consuming skill. Prosuming skill berarti bahwa prosumer dapat memproduksi isi media untuk dirinya sendiri, dan mengambil keuntungan dari keberadaan teknologi media baru.

Dalam pandangan Cen et. al, literasi media bukan hanya seperangkat kemampuan netral yang dimiliki oleh individu. Sebaliknya, literasi media melibatkan situasi sosial dan politik. Oleh karena itu, aspek kritis penting dalam literasi media guna melengkapi aspek fungsional. Aspek fungsional literasi media melibatkan kemampuan individu untuk memberi makna dan menggunakan sarana dan isi media, termasuk dalam hal ini menyangkut akses dan produksi isi media. Aspek kritis di sisi lain merujuk pada kemampuan "analyzing, evaluating, and critiquing media" (Cen et. al, 2011: 86). Literasi pada aspek ini mencakup kemampuan pengguna untuk memberi makna teks dan sosial isi media, nilai-nilai sosial, tujuan pembuat content, dan relasi kekuasaan antara pemroduser pesan dengan audiens. Lin et. al (2012: 163) mempertajam kerangka literasi media baru Cen et. al ini dengan cara mempertajam masing-masing aspek, misalnya, aspek critical consuming diturunkan ke dalam tiga indikator, yakni evaluasi, sintesis, dan analisis.

Meluasnya fenomena post-truth dalam dunia politik, terutama sejak kampanye politik di Amerika Serikat telah menjadi tantangan baru di era digital. Post -truth muncul karena banyak faktor diantaranya adalah menurunnya kepercayaan terhadap ilmu pengetahuan, ketimpangan sosial dan ekonomi, menurunnya kapital sosial (lihat Lewandowsky et.al, 2017); dan ketiadaan institusi yang memonopoli kebenaran (Kapolkas, 2019: 11). Post-truth dicirikan oleh mengaburnya batas-batas antara kebohongan dan cerita kebenaran (Keyes, 2004; seperti dikutip Kapolkas, 2019: 12).

Kehadiran media baru terutama media sosial mempunyai pengaruh besar dalam menyebarkan posttruthkarena karakteristiknya. Seperti dikemukakan Lewandowsky et.al (2017: 359), "Oneconsequenceofexposuretoideologically slanted media is the formation of inaccurate beliefs even when relevant evidence is understood correctly". Kapolkas mengemukakan bahwa era Paska-kebenaran dan Era Pengalaman (Experience Age) tidak dapat dilepaskan oleh lingkungan media. Keberadaan media tidak hanya mempengaruhi perubahan masyarakat dengan bertindak sebagai mediator ("pembawa pesan"), tapi juga keberadaan mereka, kemaha-hadiran, dan logika internal. Inilah yang kemudian disebut sebagai proses mediatisasi, yakni ketika keberadaan media pada akhirnya mempengaruhi secara mendasar praktik-praktik sosial dan politik kehidupan manusia. Termasuk dalam hal ini, cara orang-orang berbohong dalam memanipulasi pikiran orang-orang melalui praktik-praktik disinformasi.

\section{TEMUAN DAN DISKUSI}

Aplikasi percakapan WhatsApp menjadi salah satu aplikasi paling popular bagi masyarakat Indonesia. Saat ini, hampir semua orang yang menggunakan telepon pintar (smartphone) hampir dipastikan menggunakan aplikasi WhatsApp. Melalui aplikasi ini, seseorang dapat berkomunikasi dengan kata-kata (teks tertulis) ataupun berkomunikasi langsung melalui WhatsApp call. Mereka juga dapat membentuk ke- 
lompok-kelompok yang terdiri dari beragam tujuan dan partisipan. Dalam kelompok itu pula, mereka dapat berbagi informasi, berita, gambar dan juga video. Karena kemudahan inilah, banyak orang terlibat dalam lebih dari satu kelompok, dan banyak diantaranya memiliki belasan hingga puluhan kelompok percakapan WhatsApp.

Dalam kehidupan sehari-hari, WhatsApp telah menjadi ruang komunikasi manusia yang tidak terpisahkan, dan bahkan telah dianggap menstransformasi realitas sosial manusia ke dalam ruang virtual. Akibatnya, beberapa ilmuwan telah mulai melakukan studi terhadap ruang percakapan ini (Triantoro, 2019; Rianto, 2016).

Studi ini akan menguji sejauh mana post-truth terjadi dalam ruang percakapan "virtual" WhatsApp. Meskipun hoaks atau kebohongan sebagai salah satu ciri penting post-truth banyak beredar melalui media sosial seperti Facebook ataupun Twitter (lihat Mastel, 2017), tapi aplikasi percakapan seperti WhatsApp juga sangat penting (Rianto dkk, 2019) sebagai medium penyebaran hoaks. Bahkan, melalui aplikasi percakapan ini, reaksi seseorang dapat segera diidentifikasi ketika suatu pesan yang dianggap hoaks diunggah dalam percakapan. Pesan itu akan segera dikoreksi oleh anggota lain, tapi kadang kala juga menimbulkan konflik. Biasanya, konflik terjadi ketika berhubungan dengan politik atau agama. Tidak jarang, unggahan semacam itu membuat anggota kelompok lain keluar dari grup.

Penulis terlibat dalam banyak grups WhatsApp, tapi grup yang menjadi amatan penelitian yang paling dinamis. Latar belakang mereka yang sangat beragam telah menciptakan sudut pandang yang kompleks dalam melihat setiap persoalan, terutama ketika berhubungan dengan agama dan politik. Meskipun diantara anggota grup meminta agar grup tidak berbicara politik, tapi hal itu tidak pernah terwujud. Grup pernah melakukan polling, dan hanya satu orang yang menginginkan boleh bicara politik berbanding 19 orang yang menolak berbicara politik. Lainnya yang jumlahnya paling besar abstain. Kenyataannya, selalu ada anggota yang menggunggah pesan politik yang kemudian menyulut anggota lainnya untuk merespon.

Uraian berikut akan memaparkan fenomena post-truth dalam ruang percakapan "virtual" tersebut. Pada bagian berikutnya, akan dipaparkan sebab-sebab munculnya fenomena post-truth dalam kelompok tersebut. Narasi mungkin lebih condong pada kelompok tertentu atau pendukung paslon tertentu. Hal itu semata dilakukan karena keaktifan anggota tersebut, terutama dalam membangun narasi politik yang diinginkannya.

1. Post-truth di Ruang Kelompok Aplikasi Percakapan:

"Kebenaran vs Keyakinan."

Mair (2017; dikutip dari Kapolkas, 2019: 11) menyebutkan bahwa ciri era post-truth adalah ketidakjujuran baru secara kualitatif para politisi, terutama dalam hal mengarang fakta untuk mendukung apapun yang dinarasikan. Dengan kata lain, fakta dihadirkan dan dibuat secara ad hoc sesuai dengan cerita tertentu atau karena sesuai dengan agenda yang lebih luas. Fakta yang hadir dalam realitas media sosial, termasuk dalam ruang-ruang percakapan karenanya tidak pernah netral. Sebaliknya, fakta yang dihadirkan itu mencerminkan suatu hasrat politik tertentu, terutama dalam usahanya mempengaruhi persepsi orang-orang mengenai politik dan dalam konteks penelitian ini pemilihan umum. Ketika pemilu tak lagi dimenangkan, usaha berikutnya adalah melakukan deligitimasi terhadap penyelenggaraan pemilu. Dalam hal ini, tidak terlalu peduli apakah data atau fakta yang dihadirkan benar ataukah tidak, masuk akal ataukah tidak karena yang terpenting adalah tingkat dukungan fakta itu untuk membenarkan pandangan-pandangannya. Klaim atas kebenaran menjadi sederhana karena hanya soal orangorang meyakininya atau karena orang-orang ingin meyakininya (Kapolkas, 2019: 11).

Pegamatan terlibat menemukan bagaimana fenomena post-truth berlangsung dalam ruang percakapan grup selama pemilihan umum 2019. Orang-orang yang berada dalam garis dukungan pasangan calon presiden tertentu (terutama paslon 02) sangat aktif dalam mengunggah data-data dan fakta-fakta yang tampaknya akurat demi membangun narasi yang diinginkan. Anggota kelompok itu sebenarnya tidak banyak, tapi sangat aktif dalam mengunggah pesan-pesan politik yang narasinya dapat dibedakan dalam tiga isu pokok.

Pertama, pasangan 02 yang paling layak men- 
jadi presiden, sebaliknya pasangan 01 telah gagal. Narasi ini banyak dilakukan selama menjelang pemilu, dan anggota yang sama terus-menerus mengunggah artikel dan data-data untuk mendukung narasinya itu. Bahkan, hal itu dilakukan ketika masa tenang (16 April 2019) sehingga mengundang protes anggota lain hingga menciptakan kegaduhan. Pada masa tenang itu, diunggah tulisan hasil istikharoh ulama Madura yang intinya bahwa hasil istikharoh menunjukkannya untuk mendukung 02. Ada banyak kutipan ayat untuk mendukung argumen itu. Jauh di hari-hari sebelumnya, banyak unggahan artikel terutama terkait dengan imigran China atau 'penjajahan'China atas Indonesia.

Kedua, pasangan yang didukungnyalah, dalam hal ini 02, yang menang. Narasi itu disampaikan dalam beragam cerita 'faktual'atau setidaknya tampak dibuat seolah-olah faktual. Untuk mendukung narasi itu, berbagai fakta dihadirkan seperti hasil hacker terhadap situs Komisi Pemilihan Umum (KPU), hasil hitung C1 oleh kubu 02, dan seterusnya. Ini sangat jelas terlihat dari penggalan tulisan yang diunggah dari seseorang warga Indonesia yang tinggal di Jepang. Penggalan salah satu paragrafnya adalah sebagai berikut.

Pak Jokowi dan Pak Prabowo Yth,

Saya ingin berbagi info tentang pemilu dan sikap pemimpin di Jepang. Pemilu di Jepang, berlangsung aman dan damai. Tanpa ada hiruk pikuk kampanye, apalagi bagi- bagi sembako, uang, baju kaus dari pemimpinnya. Semua itu tidak pernah ada. Rakyat mereka juga tidak mau dibohongi oleh pemimpinnya. Mereka melihat kenyataan dan berfikir dengan logis, apakah seorang pemimpin bagus atau tidak. Mereka semua akan memilih sesuai dengan hati nuraninya. Biasanya, pemilihan umum menggunakan lokasi sekolah milik pemerintah, rakyat disekitar pemukiman akan datang dan antrian tertib pada hari $H$, kemudian memilih calon yang disukai. (unggahan oleh +62 815-6778-4xxx, 4/19/19, 21:23)

Paragraf di atas tampaknya netral dan objektif karena menyasar dua kandidat pemilu. Pesan ditujukan untuk Jokowi dan Prabowo. Namun, pada bagian akhir tulisan itu, dikemukakan sebagai berikut.

Pak Jokowi Yth, Legowolah, Pemilu 2019 Pak Prabowo Pemenangnya!

Saya tidak ikut dalam panitia pemilu apapun, tapi tetap dengan intensif memantau kondisi. Jujur, saya merasa capek, waktu saya sangat tersita. Saya yakin semua rakyat Indonesia mengalami hal yang sama. Mari kita sudahi dengan dewasa proses pemilu tahun ini, karena sudah jelas nyata bahwa Pak Prabowo adalah pemenangnya. (cetak miring dari penulis) (unggahan oleh +62 815-67784xxx, 4/19/19, 21:23)

Paragraf di atas kemudian diikuti dengan data-data faktual seperti kampanye Prabowo yang diikuti oleh massa yang banyak, juga $\mathrm{C} 1$ yang menurutnya dilaporkan oleh banyak koleganya di tanah air yang memilih nomor 02. Di sini, secara jelas, penulis membangun narasi mengenai kemenangan pasangan yang didukungnya, dan tampak meyakinkan karena ditulis oleh warga Indonesia yang tinggal Jepang. Unggahan semacam ini banyak dilakukan oleh orang yang sama, yang menandakan bahwa masalah ideologis sangat mewarnai tindak berkomunikasinya di dunia daring.

Ketiga, pemilu dilakukan secara tidak jujur. Lembaga quick count dan media mainstream terlibat dalam 'persekongkolan jahat'agar pemilu memenangkan pasangan 01. KPU juga dianggap sebagai pihak yang terlibat dalam persekongkolan itu. Di sini, narasi yang coba dibangun adalah membangun deligitimasi pemilihan umum. Sama seperti narasi pertama, narasi kedua juga didukung oleh data-data faktual meskipun akurasinya banyak dipertanyakan oleh anggota grup lain. Di sini, sangat mungkin bahwa 'post -truth'tidak hanya menyasar pendukung 02, tapi juga 01. Namun, para anggota grup pendukung 01 lebih sering reaktif. Mereka jarang sekali berusaha secara aktif membangun narasi kemenangan pasangan yang didukungnya, dalam hal ini 01. 


\section{Bukan Semata Masalah Literasi, tapi Etika}

Dalam kelompok percakapan yang menjadi subjek amatan, orang yang dianggap penyebar hoaks oleh anggota kelompok lainnya sebenarnya cukup literate. Mereka mampu melakukan konsumsi dan produksi teks media digital dengan baik. Mereka juga mampu melakukan analisis, evaluasi, dan kritik atas media (Cen et.al, 2011). Sebagai contoh, mereka mam$\mathrm{pu}$ melacak kecenderungan bias media mainstream dalam meliput pemilu. Namun, sikap kritis menurun begitu berhadapan dengan pesan-pesan media yang cenderung positif pada pilihan politiknya. Bahkan, pesan-pesan itu tidak lagi diperiksa ulang ketika dibagi dalam kelompok percakapan. Ini dapat dilihat dari sikap 'tak patuhnya' pada teguran anggota grup untuk mengoreksi caranya dalam berbagi informasi. Salah seorang anggota grup memberikan komentar sebagai berikut.

Sepertinya, bagi sebagian rekan kita, menyebarkan hoaks bukanlah masalah karena dianggap strategi perjuangan (jihad). Mungkin saat ini, dianggap pada situasi/kondisi perang pemikiran sehingga apapun dianggap boleh demi mencapai tujuan (respon anggota grup, +62 822-1680-4xxx, 4/20/19, 21:40).

Menurut anggota tersebut, meskipun berkalikali diingatkan bahwa apa yang telah di-share adalah hoaks, tapi hal itu tidak pernah menyurutkannya untuk berbagi informasi. "Mungkin itulah yang menyebabkan, berapa kalipun diingatkan kalau yang mereka sebar adalah hoax, tetap terus diulang”, lanjutnya.

Pemilihan umum adalah kontestasi kandidat untuk memperebutkan suara pemilih demi meraih kekuasaan, sedangkan bagi warga negara pemilihan umum adalah soal pilihan. Beberapa pemilih melakukannya karena alasan rasional dengan berorientasi pada program kerja, sedangkan lainnya sekadar kebutuhan pragmatis jangka pendek seperti mendapatkan uang. Namun, tidak sedikit pula yang pilihannya digerakkan oleh ideologi. Di sini, ideologi dipahami dalam pengertiannya yang lebih positif dan luas, yakni sebagai 'perekat sosial' suatu masyarakat atau kelompok masyarakat, mampu berperan sebagai daya penggerak tindakan (lihat Haryatmoko, 2003), dan memuat cita-cita (lihat Eagleton, 2000). Dalam konteks komunikasi, keyakinan (ideologis) itu menuntun tindakan-tindakan komunikasi dalam memilih pesan yang diakses, dikonsumsi, dan juga dibagi dalam kelompok percakapan. "Kesadaran ideologis" itu menjadi dasar 'penilaian' bagi setiap pesan/informasi yang datang padanya, menentukan kriteria menyangkut pesan mana yang sekadar dibaca, dibuang, dan yang akhirnya dibagi atau diteruskan. Semuanya didasarkan pada keyakinan-keyakinan ideologis. Seperti ditunjukkan Grossberg et.al (2006: 199), ïdeologi tidak hanya sistem partikular representasi atau cara melihat (ways of seeing), tapi juga mengeluarkan (excluding) dan membatasi (limiting) karena mereka menetapkan batas-batas pada apa yang dapat kita pahami sebaik mungkin. Ideologi, dalam kaitan ini, pada akhirnya menstrukturisasi tindakan (Haryatmoko, 2003: 16-17). Setiap kelompok dalam masyarakat akan senantiasa berusaha menunjukkan identitasnya, dan bertindak atas perhitungan akan reaksi orang lain. Ideologi mengandaikan adanya sistem makna yang dapat diperhitungkan. Ketika sistem makna tidak dapat lepas dari sistem penafsiran, maka ideologi pada akhirnya menstrukturisasi tindakan sosial karena tindakan-tindakan itu secara pasti melibatkan bidang penafsiran. Di sisi lain, menurut Haryatmoko, tindakan yang bermakna seperti halnya tindakan rasional, di mana tujuan pada akhirnya menentukan sarana dan reaksi orang lain.

Sekilas, hal itu mirip dengan penganut etika utilitarianisme (lihat Day, 2003; Rianto, 2019). Namun, sebenarnya tidaklah demikian. Sebaliknya, sejauh pengamatan di ruang media percakapan itu, tujuannya bukan semata-mata mencari kebaikan bagi sebagian besar orang seperti etika teleologi, tapi demi kendali wacana. Dengan kata lain, tujuannya adalah kekuasaan. Ideologi menjadi titik tolak berpikir dan bertindak (Haryatmoko, 2003: 19), dan menafsir realitas sosial dan media (Grossberg et.al, 2006), tapi karena ambisinya muncul ciri distorsi, yakni membelokkan maksud yang benar agar koheren dengan kenyataan. Pada akhirnya, ideologi menjadi pembenar bagi upaya dominasi (Haryatmoko, 2003: 20). 
Alasan ideologis inilah yang paling tepat untuk menjawab "sikap kepala batu" anggota grup yang selalu menyebarkan pesan politik dari media sosial ataupun internet meskipun mengandung protes dari anggota grup lainnya. Setiap informasi yang potensial mengacaukan keyakinannya dengan cepat disingkirkan atau dibantah. Dalam kelompok percakapan yang diamati dalam penelitian ini, orang-orang 'kepala batu' ini tidaklah banyak. Mereka hanya satu atau dua orang saja, tapi sangat aktif dalam berbagi informasi seperti artikel, sekadar tulisan seseorang atau link berita yang kredibilitas sumbernya seringkali diragukan. Bahkan, tidak jarang mengutip tokoh seperti Presiden BJ Habibie seperti potongan posting berikut.

Majelis Cyber Indonesia telah berhasil meretas server KPU dari luar negeri yang menyimpan data C1 yang belum dipublikasikan. Dengan gerak cepat, anak-anak muda militan ini berhasil menghitung perolehan sebenarnya hasil pilpres 2019 yang dimenangkan Prabowo-Sandi. Bapak BJ. Habibie yang mengetahui ini dari koneksinya di Jerman, langsung secara khusus memberikan ucapan selamat kepada Pak Prabowo. Begitu juga dengan beberapa Dubes Negaranegara Eropa turut memberikan ucapan selamat. ...... (unggahan oleh +62 815-67784xxx: Gempar Ternyata Ini Hasil Rekapitulasi Suara Pilpres 2019 Berdasarkan C1, 4/20/19, 07:12)

Kutipan di atas merupakan paragraf pembuka yang diikuti dengan hasil perhitungan $\mathrm{C} 1$ di 34 daerah pemilu, termasuk pemilihan luar negeri. Total suara yang masuk sebagaimana dapat dilihat dalam unggahan itu adalah 133. 574.277. Unggahan dilakukan pada 20 April 2017. Menurut hitungan akhir KPU, perolehan paslon 01 adalah 84.646 .196 (55.32\%), sedangkan paslon 2 adalah 68. 357.813 (44.68\%). Total suara keduanya 153.004.009. Jika dibandingkan dengan hitungan akhir KPU ini, maka total suara yang diunggah dalam waktu 3 hari telah mencapai $87.3 \%$. Dengan common sense, hal itu tidak mungkin. Indonesia adalah wilayah yang luas dengan banyak kesulitan geografis (wilayah pegunungan dan pulau-pulau terpencil). Na- mun, informasi itu tetap dibagi dalam kelompok karena secara ideologis menguntungkan posisinya.

Hasrat ideologis untuk mendukung pasangan calon tertentu membuatnya sangat aktif, dan secara konsisten membagi informasi dalam kelompok percakapan. Ia aktif dalam men-share informasi yang mendukung paslon 02 , sedangkan pendukung paslon 01 -yang tampaknya lebih banyak-justru lebih sering merespon unggahan.

Dari pengamatan beberapa bulan, dapat disimpulkan bahwa orang-orang yang aktif ini adalah anggota kelompok dengan literasi digital yang baik. Mereka mampu memproduksi dan berbagi pesan dalam kelompok percakapan. Mereka aktif berbagi pesan dan tampaknya terlibat dalam penyebaran hoaks yang disengaja (intended hoax). Ini telah menjadi suatu ciri penyebaran hoaks politik dalam era post-truth (lihat Kapolkas, 2019; Block, 2019; Marshal dan Drieschova, 2018).Studi Schradie (2015) juga menunjukkan bahwaketerikatan ideologis menentukan keterlibatannya dalam media sosial. Hal ini karena ideologi menentukan pola-pola pengorganisasian. Jadi, semakin kuat ideologi seseorang akan semakin kuat pula keterlibatannya di media sosial. Hasil studi ini nampaknya juga demikian. Alasan ideologis membuatnya lebih aktif dibandingkan kelompok lain dalam memposting pesan-pesan politik pemilu meskipun banyak keberatan diajukan atas unggahan itu. Dengan demikian, dalam kasus ini, dapat dikatakan bahwa masalah utama bukan terletak pada literasi digital, tapi pada etika komunikasi di media sosial.

Secara sederhana, etika berhubungan dengan baik buruk, terkait dengan nilai-nilai dan moralitas (lihat Bertens, 2013; Haryatmoko, 2007). Ajaran-ajaran etika biasanya bersandar pada deontologi (Kant) dan teleologi (John Stuart Mill). Kedua ajaran etika ini bertolak belakang, fokusnya pada kebaikan atau kemanfaatan. Bagi etika deontologi, tujuan tindakan etis adalah demi mewujudkan kewajiban manusia universal. Oleh karena itu, suatu perbuatan baik akan diukur apakah perbuatan itu sesuai dengan norma atau kewajiban universal. Maka, berbohong dalam kondisi apapun adalah tidak etis karena keliru menurut moral universal. Dalam etika deontologi, tujuan tidak boleh 
menghalalkan cara. Di sisi lain, bagi etika teleologis, titik beratnya pada tujuan atau konsekuensi. Jika suatu tindakan mempunyai manfaat yang baik, maka tindakan tersebut etis. Berbohong diperkenankan jika memang demi tujuan lebih mulia. Meskipun demikian, seperti dikemukakan oleh Haryatmoko, "tujuan menghalalkan sarana" harus diberi catatan bahwa tujuan-tujuannya baik. Sebaliknya, tujuan demi sematamata membelokkan kebenaran demi kekuasaan atau dominasi wacana tidak dapat dianggap sebagai tindakan etis. Dengan dasar pijakan demikian, dapat dijelaskan mengapa orang-orang dengan tingkat pendidikan tinggi mampu bertindak secara sembarangan dalam menyebarkan hoaks, dan ketika mendapatkan teguran anggota lainnya tidak terungkapkan permintaan maaf. Ideologi yang membawanya pada suatu keyakinan tertentu telah menutup diri atas informasi lain, dan bahkan menutupnya dari kesalahan yang dibuatnya. Ideologi, dalam hal ini, menginterpelasi, memanggil individuindividu sebagai "subjek-subjek konkret" dengan menfungsikannya sebagai kategori subjek (Althusser, 2008: 51). Ideologi politik telah memanggil subjek tadi untuk menjadi bagian dari kategori subjek yang dikehendaki (oleh suatu ideologi politik tertentu) sehingga setiap tindakan komunikasi sedemikian rupa dipengaruhi oleh posisinya sebagai 'subjek ideologi' tadi. Akibatnya, segala tindakan dianggap sebagai kebenaran karena orientasinya pada tujuan yang dirumuskan oleh subjeksubjek ideologis tadi.

\section{KESIMPULAN}

Penelitian ini ingin menjelaskan hoaks politik dalam ruang media percakapan yang terjadi di antara para profesional. Kesimpulannya bahwa post-truth tidak disebabkan oleh semata rendahnya literasi digital, tapi lebih pada kurangnya etika. Politik pemilu telah membelah individu-individu ke dalam dua kelompok, dan masing-masing menjadi subjek ideologisnya sendiri-sendiri. Subjek-subjek ideologis inilah yang kemudian menafikkan tindakan etis komunikasinya karena ideologi mempengaruhi cara ia menafsir realitas pesan media dan menampilkannya dalam ruang percakapan. Akibatnya, muncul rasionalitas instrumen- tal di mana "tujuan menghalalkan cara". Meskipun demikian, tidak berarti bahwa literasi digital tidaklah penting. Sebaliknya, literasi digital haruslah menjadi bagian penting dalam usaha menanggulangi atau setidaknya meminimalkan perluasan fenomena posttruth.Namun, ada soal lain yang menyebabkan hoaks dan post-truthmenyebar dalam kelompok percakapan, yakni kurangnya etika.

Kontribusi penelitian ini kiranya terletak pada usahanya untuk melihat fenomena hoaks dan post-truth di media sosial atau, dalam kajian ini, kelompok percakapan WhatsApp, yang tidak semata dilihat dari perspektif literasi digital, tapi juga etika. Perhatian secara luas telah diberikan oleh para sarjana dan masyarakat sipil di Indonesia terkait dengan literasi digital sebagaimana diprakarsai diantaranya oleh Japelidi, tapi tidak demikian dengan etika media sosial. Oleh karena itu, dua jalur pemberdayaan para pengguna media sosial melalui literasi digital dan etika adalah keharusan untuk menciptakan suatu tatanan komunikasi di media sosial yang jauh lebih positif. Studi-studi etika komunikasi di media sosial karenanya harus berjalan seiring dengan studi-studi dan gerakan literasi digital. Hal itu karena baik literasi digital maupun etika mempunyai tujuan yang berbeda. Tujuan literasi demi meningkatkan kapasitas pengguna dalam menggunakan media sosial secara kritis, sedangkan etika menuntun pengguna untuk selalu reflektif dalam berkomunikasi. Etika memandu para pelaku komunikasi untuk selalu mempertimbangkan komunikasi apakah sesuai dengan norma dan memberi manfaat ataukah tidak.

\section{DAFTAR PUSTAKA}

Aguaded-Gómeza, Ignacio, Tirado-Morueta, \& Ramón Hernando-Gómez, Ángel (2014). Media competence in adult citizens in Andalusia, Spain. Information, Communication \& Society, Routledge Taylor and Francis Grup, $\quad$ pp. 1-21, $\underline{\text { http:// }}$ dx.doi.org/10.1080/1369118X.2014.985244

Althusser, Louis (2008). Tentang Ideologi: Marxisme Strukturalis, Psikoanalisis, Cultural Studies. Terjemahan Olsy VA. Yogyakarta: Jalasutra 
Ashley, Seth, Maksl, Adam, \& Craft, Stephanie (2017). News Media Literacy and Political Engagement: What's the Connection? Journal of Media Literacy Education 9 (1), pp. $79-98$

Bertens, K (2013). Etika. edisi revisi. Yogyakarta: Kanisius

Block, David (2019). Post-truth and Political Discourse. Cham: Palgrave Macmillan

Cen, Der-Thanq "Victor", WU, Jing \& WANG, Yumei (2011). Unpacking New Media Literacy. Systemics, Cybernetics and Informatics, Volume 9 - Number 2 - YEAR 2011, pp. 84-88

Chaffee, Stephen H dan J. Metzger, Mirriam (2001). The End of Mass Communication? Mass Communication \& Society, 2001, 4(4), pp. 365-379

Croteau, David \& Hoynes, William (2006). The Business of Media: Corporate Media and the Public Interest. Second edition. Thousand Oaks, London, New Delhi: Pine Forge Press

Day, Louis Alvin (2003). Ethics in Media Communications Cases and Controversies. Fourth edition. United States: Thompson dan Wadswort

Eagleton, Terry (2000). Ideology: an Introduction. Sevent impression. London-New York: Verso

Eshet-Alkalai, Yoram (2004). Digital Literacy: A Conceptual Framework for Survival Skills in the Digital Era. Journal of Educational Multimedia and Hypermedia, 13 (1), 93-106

Galih, Aulia Puspaning (2017). Jari Selayak Duri. INFORMASI Kajian Ilmu Komunikasi, Volume 47. Nomor 2. Desember 2017, pp. 181-195

Grossberg, Lawrence; Wartella, Ellen, Whitney, D. Charles, \& Wise, J. Macgregor. (2006). Media Making: Mass Media in Popular Culture. Second edition. Thousand Oaks, London, New Delhi: Sage Publication

Guntarto, B (2011). Perkembangan Literasi Media di Indonesia. Makalah Konferensi Nasional Literasi Media, Yogyakarta, 5-6 Januari 2011, Program Studi UIIRumah Sinema

Hanugraheningtias, Arvinda Relasi Etika, Bisnis Media, dan Masyarakat Tontonan Yang Diciptakannya
(Analisis Tayangan Pernikahan Raffi Ahmad - Nagita Slavina. Jurnal Interaksi, vol. 4 No. 1, Januari 2015: 90-100

Haryatmoko (2007). Etika Komunikasi: Manipulasi Media, Kekerasan dan Pornografi. Yogyakarta: Kanisius

Haryatmoko, (2003). Etika Politik dan Kekuasaan, Jakarta: Kompas

Jatmiko, Mochamad Iqbal (2019). Post-Truth, Media Sosial, dan Misinformasi: Pergolakan Wacana Politik Pemilihan Presiden Indonesia Tahun 2019, Jurnal Tabligh Volume 20 No 1, Juni $2019: 21$ - 39

Juliswara, Vibriza (2017). Mengembangkan Model Literasi Media yang Berkebhinnekaan dalam Menganalisis Informasi Palsu (Hoax) di Media Sosial. Jurnal Pemikiran Sosiologi, Volume 4 No. 2, pp. 142 164

Kapolkas, Ignas (2019). A Political Theory of Posttruth. Springer Nature Switzerland AG: McMillan Palgrave

Kozinets, Robert V (2015). Netnography: Redefined, $2^{\text {nd }}$ edition. Los Angeles, London, New Delhi: Sage Publications

Kelkar, Shreeharsh (2019). Post-truth and the Search for Objectivity: Political Polarization and the Remaking of Knowledge Production. Engaging Science, Technology, and Society 5 (2019), 86-106, DOI:10.17351/ ests 2019.268

Kurnia, Novi \& Astuti, Santi Indra (2017). Peta Gerakan Literasi Digital di Indonesia: Studi Tentang Pelaku, Ragam Kegiatan, Kelompok Sasaran dan Mitra, INFORMASI Kajian Ilmu Komunikasi, Volume 47. Nomor 2. Desember 2017, pp. 149-166

Lewandowsky, Stephan; Ullrich KH Ecker, dan John Cook (2017). Beyond Misinformation: Understanding and Coping With the "Post-truth"Era, Journal of Aplied Research in Memory and Cognition 9 (2017) 353-369

Lin, T.-B., JY., Li, F. Deng, \& Lee, L (2013). Understanding New Media Literacy: An Explorative Theoretical Framework. Educational Technology \& Society, 
16 (4), $160-170$

Lister, Martin, Dovey, John, Giddings, Seth, Grant, Iain \& Kelly, Kieran (2009). New Media: Critical Introduction. Second edition. London and New York: Routledge

Madrah, Muna Yastuti dan Mubarok (2018). Netizen dalam Kampanye Pilpres RI 2014. Interaksi, Vol. 7, No. 1, Juni 2018, pp. $16-25$

Masyarakat Telekomunikasi Indonesia (Mastel) (2017). Hasil Survey Mastel Tentang Wabah Hoax Nasional by https://www.bkkbn.go.id/po-content/uploads/

Info-

grafis_Hasil_Survey_MASTEL tentang_Wabah_Hoax Nasional.pdf

McNair, Brian (2003). An Introduction to Political Communication. Third edition. London-New York: Routledge

Marshall, Hannah \& Alena, Drieschova (2018). Posttruth Politics in the UK's Brexit Referendum, New Perspectives Vol. 26, No.3/2018, pp. 85-105

Miles, Mathew B \& Haberman, A. Michael (2005). Analisis Data Kualitatif: Buku Sumber tentang MetodeMetode Baru. Terjemahan Tjetjep Rohendi. Jakarta: UI Press

Moravec, Patricia, Minas, Randall K. \& Dennis, Alan R. (2018). Fake News on Social Media: People Believe What They Want to Believe When it Makes No Sense at All. SSRN Electronic Journal, January 2018, DOI: 10.2139/ssrn.3269541

Mutmainnah, Nia (2011). Kegiatan Literasi Media Berbasis Sekolah: Pengalaman LSM dan Regulator. Makalah Konferensi Nasional Literasi Media, Yogyakarta, 5 -6 Januari 2011, Program Studi UII-Rumah Sinema

Nasrullah, Rulli (2017). Media Sosial: Perspektif Komunikasi, Budaya, dan Sosioteknologi, Bandung: Simbiosa Rekatama Media

Neumann, Michelle M., Finger, Glenn, \& Neumann, David L. (2017). A Conceptual Framework for Emergent Digital Literacy. Early Childhood Educ J (2017) 45:471-479, DOI 10.1007/s10643-016-0792-Z

Nichols, Tom (2019). Matinya Kepakaran: Perla- wanan terhadap Pengetahuan yang Telah Mapan dan Mudaratnya. Terjemahan oleh Ruth Meigi P. Jakarta: Kompas Pustaka Gramedia

Poerwaningtias, Intan, Puji Rianto, Maulin Niam, Wisnu Martha Adiputra, dkk (2009). Model-Model Gerakan Literasi Media \& Pemantauan di Indonesia. Yogyakarta: PKMBP-Yayasan Tifa

Potter, James W (2011). Media Literacy. $5^{\text {th }}$ edition. Los Angeles, London, New Delhi: Sage Publications

Rahmah, Amalia (2015). The Third Information Systems International Conference Digital Literacy Learning System for Indonesian Citizen. Procedia Computer Science 72 ( 2015 ) $94-101$

Rianto, Puji, Rahayu, Wahyono, Bayu dkk (2019). Hoaks Politik: Peta, Isu, dan Persebarannya di Media Sosial (Laporan Penelitian tidak dipublikasikan). Yogyakarta: PR2Media-Kemkominfo

Rianto, Puji (2019). Filsafat dan Etika Komunikasi. Yogyakarta: Universitas Islam Indonesia

Rianto, Puji (2016). Media Baru, Visi Khalayak Aktif dan Urgensi Literasi Media. Jurnal Komunikasi, Vol. 01 (02), 2016. 90-96

Sarwono, Billy, Hendriyani, B. Guntarto (2011). Efektivitas Pendidikan Media dalam Mengubah Konsumsi Media Anak: Eksperimen terhadap Siswa SD di Jawa Tengah dan Jawa Timur. Makalah Konferensi Nasional Literasi Media, Yogyakarta, 5-6 Januari 2011, Program Studi UII-Rumah Sinema

Schradie, Jen (2015). Political Ideology, Social Media, and Labor Unions: Using the Internet to Reach the Powerful, Not Mobilize the Powerless. International Journal of Communication 9(2015), 1985-2006

Storey, John (1996). Cultural Studies and the Study of Popular Culture: Theories and Methods. Athen: The University of Georgia Press

Swigger, Nathaniel (2012). The Online Citizen: Is Social Media Changing Citizens'Beliefs About Democratic Values? Polit Behav. original paper. DOI 10.1007/s11109-012-9208-y

Triantoro, Dony Arung (2019). Konflik Sosial dalam Komunitas Virtual di Kalangan Remaja. Jurnal komu- 
nikasi, Volume 13, Nomor 2, April 2019, Hal 135-150,

DOI: 10.20885/komunikasi.vol13.iss2.art2

Turow, Joseph (2014). Media Today: Mass Communication in a Converging World. Fifh edition. New York and London: Routledge

Vanwynsberghe, Hadewijch, Boudry, Elke, \& Verdegem, Pieter (2011). Mapping Social Media Literacy Toward Conceptual Framework, Desember 2011. IBBT- Interdisciplinary Institute for Broadband Technology \& Research group for Media and ICT: Ghent University by https://biblio.ugent.bel publication/3047212/file/3047219

(2019). Hasil hitung Suara Pemilu Presiden dan Wakil Presiden RI 2019. By https:// pemilu2019.kpu.go.id/\#/ppwp/hitung-suaral 